\title{
Związki koordynacyjne rutenu jako leki w nowoczesnej terapii przeciwnowotworowej
}

\author{
Urszula Śliwińska-Hill, Joanna Celmer
}

Badania związków koordynacyjnych metali jako potencjalnych leków przeciwnowotworowych doprowadziły do odkrycia unikalnych właściwości kompleksów rutenu. Pośród tej grupy związków chemicznych dwa kompleksy — NAMI-A i KP1019 — weszły do badań klinicznych i pozytywnie zakończyły ich pierwszą fazę. Przeprowadzone testy pokazały, że NAMI-A posiada doskonałe właściwości antymetastatyczne, natomiast KP1019 wykazuje wysoką aktywność przeciwnowotworową, w szczególności w stosunku do komórek nowotworowych jelita grubego. Obok dwóch wymienionych związków również metaloorganiczne kompleksy rutenu, RM175, RAPTA-T, RDC11 czy DW1/2, wydają się bardzo obiecujące jako potencjalne leki w terapii przeciwnowotworowej.

\section{Ruthenium coordination compounds as drugs in modern anticancer therapy}

The study of metal coordination compounds for the treatment of cancer has resulted in the identification of some unique properties of ruthenium complexes as antitumour agents. Among these group two of them, NAMI-A and KP1019 have entered the clinical trials with patients. The studies showed that NAMI-A inhibits the formation of metastases and KP1019 demonstrates exciting anticancer activities especially in colorectal carcinoma. As well as these two compounds, organometallic ruthenium-based complexes RM175, RAPTA-T, RDC11 and DW1/2 are very promising in the antitumour therapy.

NOWOTWORY Journal of Oncology 2015; 65, 6: 517-528

Słowa kluczowe: kompleksy metali w terapii przeciwnowotworowej, związki koordynacyjne i metaloorganiczne rutenu, NAMI-A, KP1019

Key words: metal complexes in anticancer therapy, ruthenium coordination and organometallic compounds, NAMI-A, KP1019

\section{Wprowadzenie}

Na przestrzeni ostatnich dekad zsyntetyzowano wiele dziesiątek związków kompleksowych rutenu, badając je następnie w kierunku aktywności biologicznej. Wyniki tych badań dowodzą, że wybrane kompleksy mogą zostać wykorzystane w terapii chorób nowotworowych, a w szczególności guzów odpornych na obecnie stosowaną chemioterapię oraz ognisk przerzutowych.

Jon rutenu posiada kilka właściwości teoretycznie usposabiających związki tego metalu do użycia w praktyce klinicznej. Zalicza się do nich $\mathrm{m}$. in. wolną kinetykę reakcji wymiany ligandów, liczne stopnie utlenienia, podleganie reakcjom bioredukcji, a także zdolność jonów rutenu do "upodabniania" się do innych metali podczas wiązania z biomolekułami.

Związki rutenu charakteryzują się wysoką stabilnością kinetyczną. Szybkość reakcji wymiany ligandów wyraża się w minutach do dni, a nie - jak w przypadku innych związków koordynacyjnych — w mikrosekundach do sekund. Reakcje wymiany małych ligandów w przypadku kompleksów Ru(II) i Ru(III) - podobnie jak Pt(II) - trwają kilka godzin, odzwierciedlając skalę czasu potrzebne-

Katedra i Zakład Chemii Analitycznej

Uniwersytet Medyczny im. Piastów Śląskich we Wrocławiu 
go na procesy podziału komórek. Właściwość ta chroni związki rutenu przed wchodzeniem w gwałtowne reakcje zaburzające równowagę. Dodatkowo związki Ru(II) wykazują silne termodynamiczne preferencje do wiązania się z ligandami S-donorowymi, np. GSH czy metioniną, natomiast wykazują małe powinowactwo do ligandów O- i N-donorowych [1].

Najtrwalsze stopnie utlenienia rutenu to II, III i IV, a powstające kompleksy mają głównie oktaedryczną geometrię. Relatywnie obojętne związki Ru(III) w środowisku o niższym pH ulegają redukcji do bardziej aktywnych form Ru(II). W komórkach nowotworowych, w związku ze zwiększoną aktywnością metabolizmu, jest zmniejszone stężenie tlenu, występuje wyższy poziom GSH i niższe $\mathrm{pH}$, co w efekcie tworzy wysoce redukujące środowisko [1]. Modyfikując potencjał redox, można zwiększyć selektywność działania leku wyłącznie do hipoksemicznych komórek nowotworowych, w których zachodziłaby redukcja do aktywniejszej formy Ru(II), a przy tym również ograniczyć toksyczność w stosunku do zdrowych komórek organizmu. Wykazano, że aktywność biologiczna związków opartych na metalach w dużej mierze zależy od ich geometrii i charakteru ligandów, co wpływa na bioaktywację związku [2].

Jony rutenu wykazują ponadto niezwykłą zdolność,naśladowania”jonów żelaza i wiązania z białkami, a w szczególności z transferyną [3]. Ze względu na zwiększoną ekspresję receptorów transferyny w błonach zewnętrznych komórek szybko dzielących się zaobserwowano od dwu- do dwunastokrotnie wyższe stężenie jonów rutenu w komórkach nowotworowych w porównaniu z komórkami prawidłowymi [4]. Właściwość ta pozwala pokładać nadzieję w kompleksach rutenu na eliminację systemowej toksyczności i licznych efektów ubocznych w trakcie terapii przeciwnowotworowej.

\section{Ruten a platyna}

Wysoka skuteczność kompleksów platyny (cisplatyna, carboplatyna, oxaliplatyna) w terapii chorób nowotworowych spowodowała wzrost zainteresowania innymi związkami koordynacyjnymi pod kątem ich zastosowania w medycynie. Po obiecujących wynikach I fazy badań klinicznych ogromne nadzieje pokłada się właśnie w kompleksach rutenu. Nowo zsyntetyzowane, omówione poniżej związki porównywano do modelowego cytostatyku — cisplatyny. Zauważono szereg różnic pomiędzy tymi grupami czynników przeciwnowotworowych, z których wybrane zostały przedstawione.

Przede wszystkim występują znamienne różnice w strukturze i właściwościach chemicznych kompleksów platyny i rutenu. Pierwsza to geometria związków — oktaedryczna dla związków rutenu, płaska kwadratowa dla jonów platyny(II). Kolejną odmienną cechą jest łatwość przenoszenia elektronów w parze Ru(III)/Ru(II), natomiast redukcja Pt(IV) do Pt(II) skutkuje zarówno w zmianie liczby koordynacyjnej, jak i długości wiązań pomiędzy atomami cząsteczki [5].

Występują również liczne różnice w aktywności biologicznej związków. Cytostatyki na bazie rutenu wydają się akumulować preferencyjnie w masie nowotworu poprzez transport przez transferynę, jednakże nie wykazują powinowactwa do zdrowych, niezmienionych komórek. Związki Ru(III) pozostają relatywnie nieaktywne, dopóki nie osiągną przestrzeni nowotworu, w którego środowisku następuje ich redukcja do aktywnej formy Ru(II). Aktywacja przez redukcję skutkuje nie tylko nakierowaniem leku na miejsce działania, ale także celowaną cytotoksycznością wobec hipoksemicznych komórek często odpornych na klasyczną chemioterapię kompleksami platyny. Istotną różnicą jest również skuteczność związków rutenu przeciwko komórkom przerzutów.

Z farmakologicznego punktu widzenia zauważalny jest także odmienny profil efektów ubocznych i wyraźnie mniejsza toksyczność związków rutenu w opozycji do kompleksów platyny, co czyni te pierwsze bardzo atrakcyjnymi w rozwoju chemioterapii [5]. Leki na bazie rutenu tworzą - podobnie jak cisplatyna - wiązania z nukleotydami i DNA, jednak proces ten przebiega znacznie wolniej w porównaniu z połączeniami platyny. Z obserwacji wynika, że najlepszym partnerem do stworzenia wiązania jest w obu przypadkach guanina, nawet przy dużym nadmiarze pozostałych zasad nukleinowych. Kompleksy rutenu wykazują zdolność utworzenia wiązania również $\mathrm{z}$ adeniną i tyminą. Stwierdzono prawidłowość malejącego stopnia tworzenia wiązań z DNA w szeregu: cisplatyna > oxaliplatyna > NAMI-A > RAPTA-T > karboplatyna > KP1019 [6].

\section{Charakterystyka związków rutenu o aktywności przeciwnowotworowej NAMI-A}

NAMI-A [(Him)[trans-Ru'IICCl${ }_{4}$ (DMSO)(Im)], Im-imidazol (ryc. 1) jest pierwszym nieplatynowym lekiem na bazie metalu, który z sukcesem zakończył I fazę badań klinicznych, obejmującą grupę 24 pacjentów z różnymi histotypami nowotworów, po wcześniej resekcji guza, chemio- lub radioterapii $[7,8]$.

Kompleks ten jest związkiem antyangiogennym. Jego właściwości przeciwinwazyjne sprawiają, że jest to aktywny czynnik w stosunku do przerzutów nowotworowych [9]. W próbnych testach przesiewowych w kierunku aktywności przeciwnowotworowej nie dawał zadowalających efektów w stosunku do guzów pierwotnych, wykazał natomiast działanie zapobiegające rozwojowi i inhibicję wzrostu przerzutów w obrębie układu oddechowego wywodzących się z guzów litych [10]. Ponadto najnowsze prace donoszą o wysokiej i selektywnej cytotoksyczności NAMI-A w stosunku do linii komórek białaczkowych, zarówno szpikowych (K562, FLG29.1, HL60) jak i limfatycznych (REH, 697) [11]. 


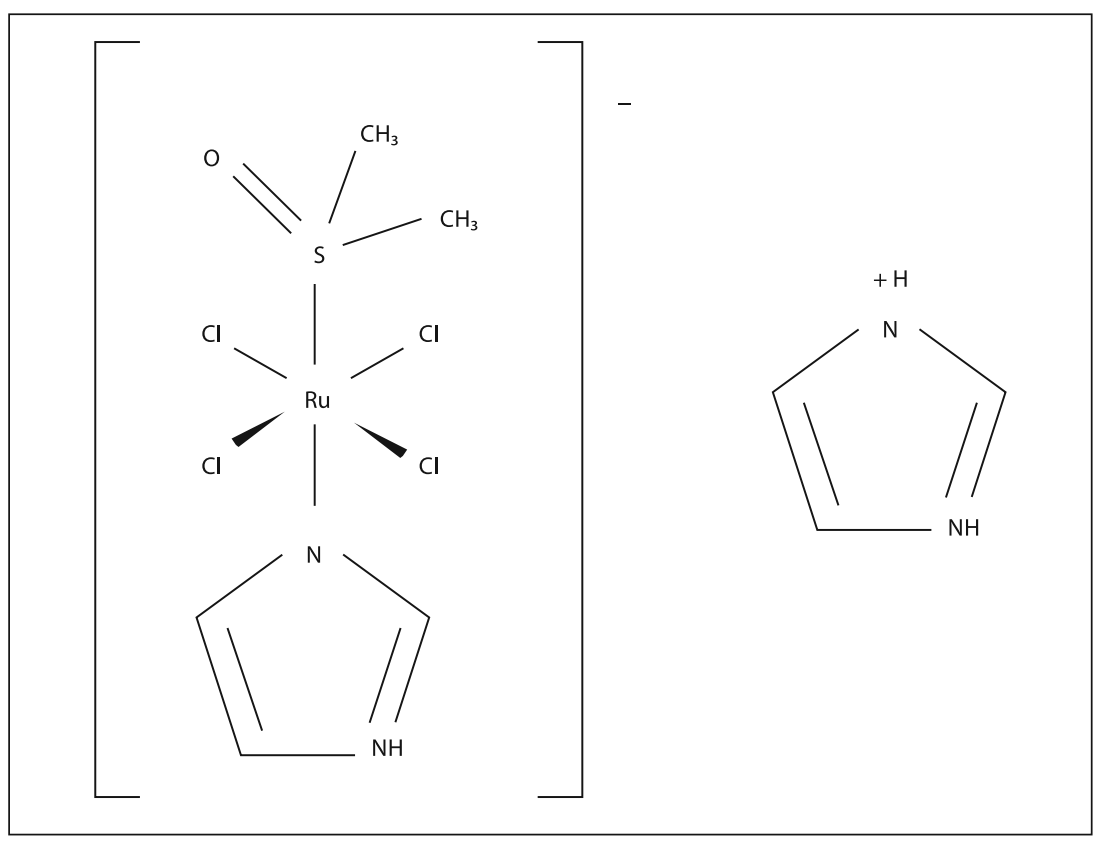

Rycina 1. Wzór strukturalny NAMI-A

Badania pokazały, że efekt przeciwprzerzutowy NAMI-A nie zależy od stadium rozwoju przerzutów i że jego skuteczność jest porównywalna w przypadku zaawansowanej metastazy, jak również po chirurgicznym usunięciu guza pierwotnego.

Mechanizm działania NAMI-A może być przypisany wielu wewnątrz- i pozakomórkowym oddziaływaniom. Kompleks ten blokuje progresję cyklu komórkowego w fazie $\mathrm{G}_{2} / \mathrm{M}[12]$, reguluje aktynozależną adhezję i przebudowuje cytoskeleton z inhibicją inwazyjności i metastazy [13-15]. Ponadto aktywność biologiczna leku obejmuje: inhibicję PKC regulowaną aktywnością ERK1/2 c-Myc, prowadzącą do apoptozy w transformowanych komórkach śródbłonka [16, 17], wiązanie z zewnątrzkomórkową macierzą kolagenową i generowanie aktywności antyangiogennej w guzie pierwotnym i modelach VEGF z indukowaną neoangiogenezą [18, 19], ułatwianie oddziaływań pomiędzy komórkami nowotworowymi i naciekiem limfocytów poprzez modulację ekspresji CD44 i ICAM-1, odpowiednio w komórkach nowotworowych i limfocytach [20, 21], usuwanie komórek przerzutów z heterogennych komórek guzów pierwotnych [22, 23].

W większości cytotoksyczność związków rutenu łączy się bezpośrednio z ich zdolnością wiązania z DNA. Wyjątek stanowi przeciwprzerzutowa aktywność NAMI-A, która prawdopodobnie nie jest związana z deformacją kwasów nukleinowych [24]. Zaobserwowano jego znaczącą efektywność w komórkach przerzutowych w płucach, gdzie okres półtrwania związku jest ok. ośmiokrotnie dłuższy niż w masie guza pierwotnego, prawdopodobnie z powodu dużej zawartości kolagenu, z którym NAMI-A efektywnie się łączy. Omawiany związek oddziałuje poprzez aktywność ko- lagenolityczną typu IV i zmniejsza potencjał przerzutowania nowotworu zasadniczego [24].

Większej aktywności w guzach przerzutowych do płuc, w porównaniu z pierwotnymi nowotworami, nie przypisuje się jednak wyłącznie farmakokinetyce in vivo NAMI-A. Wprowadzając lek bezpośrednio do guza, osiąga się dziesięciokrotnie większe stężenie rutenu w tej tkance, ale ograniczenie wzrostu guza pierwotnego jest wciąż niewielkie w porównaniu z przerzutami do płuc. Dane te podkreślają hipotezę istnienia znacznych różnic w komórkach guzów przerzutowych i guza pierwotnego oraz selektywność NAMI-A wobec tych pierwszych. Dalsze badania wykazują, że związek ten jest w stanie zaatakować komórki przerzutów niezależnie od miejsca lokalizacji. Oczywiste okazało się, że komórki wrażliwe na NAMI-A to tylko komórki ognisk przerzutowych, mające klonogenne pochodzenie, które w masie guza zasadniczego są małą populacją. W wyniku ich eradykacji z guza pierwotnego nie dochodzi do znaczącej redukcji objętości guza, natomiast odległe homogenne ogniska przerzutowe niszczone są niemal całkowicie. Selektywną redukcję ognisk przerzutów nowotworowych przedstawia rycina 2 [25].

Badania wykazały, że mechanizm kontroli przerzutów nowotworowych NAMI-A można przypisać łącznej aktywności antyangiogennej i antyinwazyjnej na komórki guza i naczynia krwionośne, co jest przedstawione na rycinie 3. Na poziomie molekularnym NAMI-A blokuje kinazy aktywowane miogenami lub inaczej: pozakomórkowe sygnały regulacji szlaku kinaz w komórkach śródbłonka, prawdopodobnie z powodu zahamowania błonowej kinazy białka C (PKC). Proces ten prowadzi do zatrzymania transkrypcji genu c-Myc 


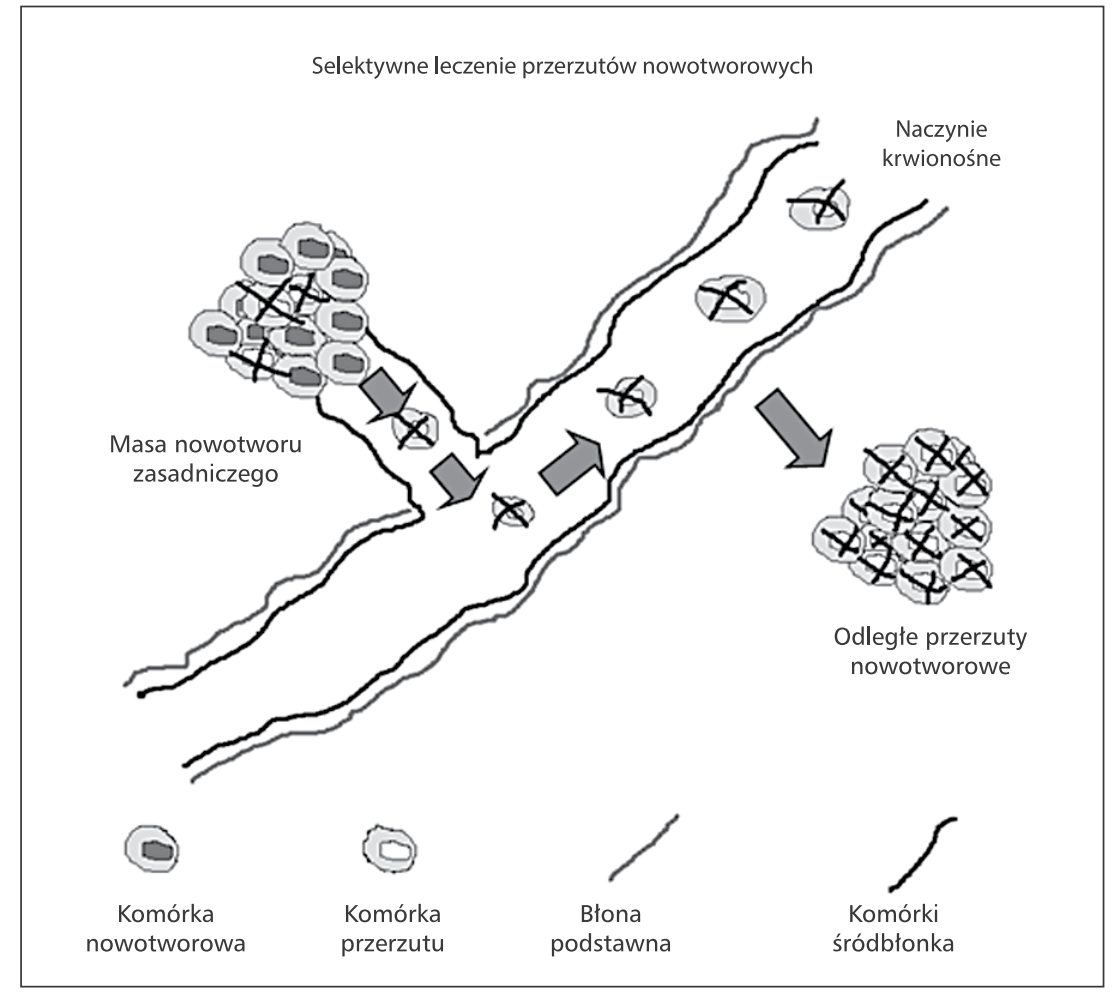

Rycina 2. Selektywne usuwanie przerzutów przez NAMI-A [9]

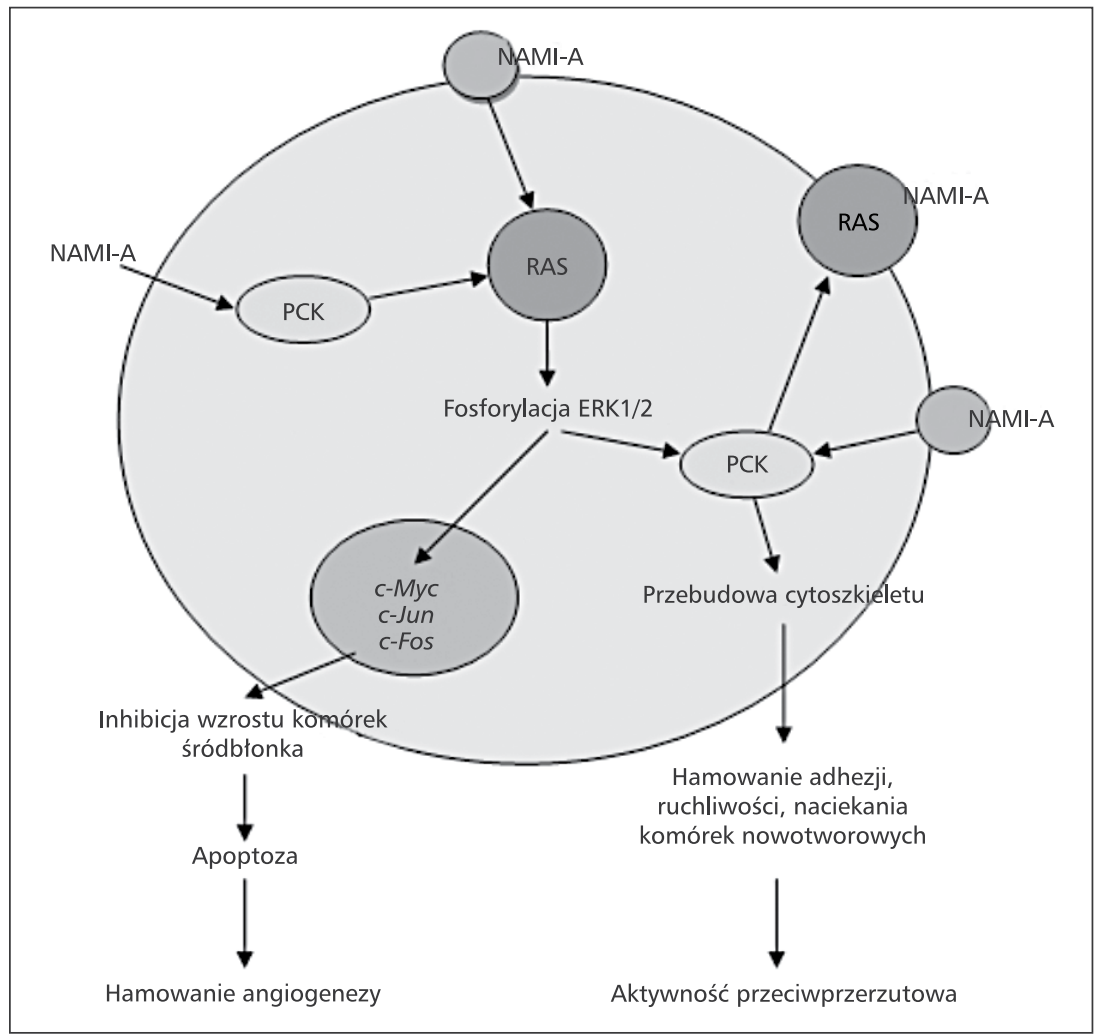

Rycina 3. Schemat mechanizmu działania NAMI-A oraz jego wpływu na komórki nowotworowe i komórki śródbłonka naczyń [9] 


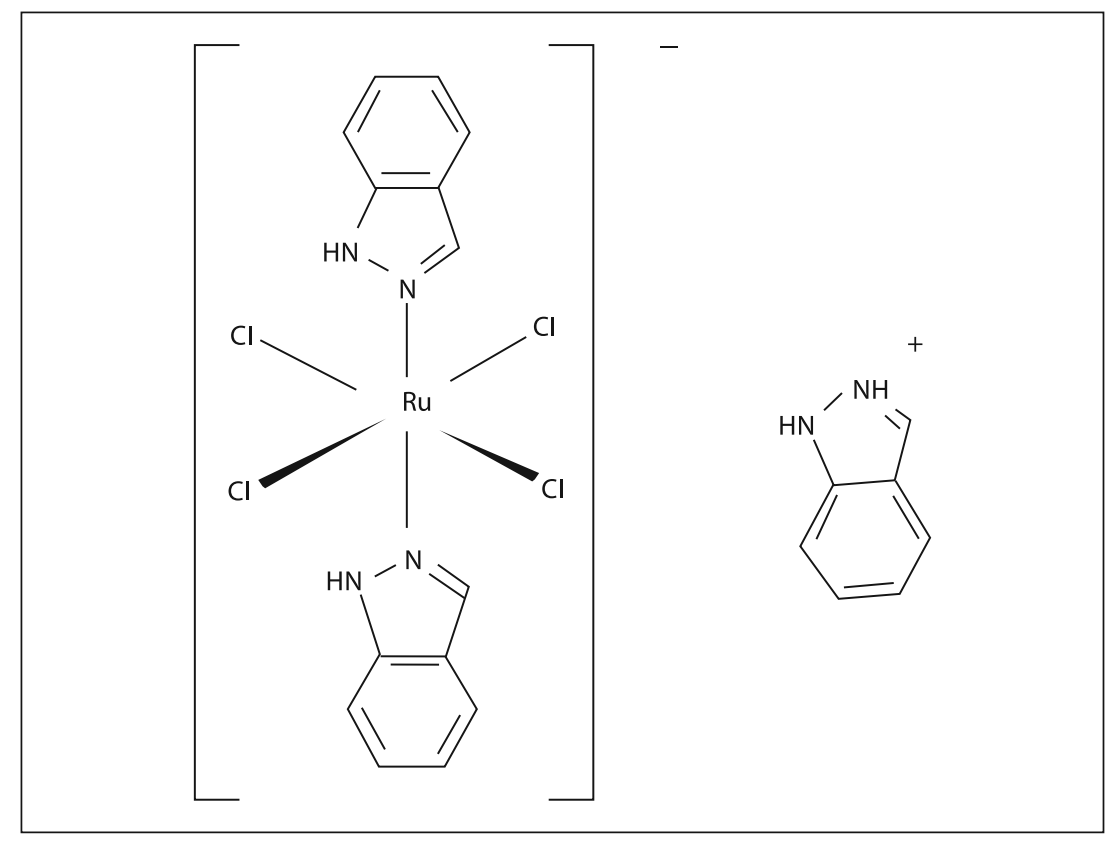

Rycina 4. Wzór strukturalny KP1019 (FFC14a)

— onkogenu odpowiedzialnego za procesy angiogenezy oraz aktywacji kaspazy 3 (kluczowej kaspazy w wykonawczej fazie zaprogramowanej śmierci komórki) [10].

Działanie NAMI-A polega na zmniejszeniu spontanicznego naciekania przez komórki nowotworowe okolicznych zdrowych komórek i naczyń krwionośnych oraz aktywacji molekuł adhezyjnych takich jak beta-integryny. CD44 - glikoproteiny powierzchni komórek zaangażowane w interakcje komórka/komórka i komórka/macierz, są również modulowane przez NAMI-A, co w efekcie powoduje namnożenie limfocytów guza, zmiany kształtu komórki, przebudowę cytoszkieletu, zmniejszenie rozrostu przerzutów. Oddziaływanie NAMI-A na CD44 ma duże znaczenie także $z$ uwagi na jego rolę w szlaku aktywacji transkrypcji c-Met — onkogenu związanego z przerzutami [10].

NAMI-A był pierwszym lekiem na bazie rutenu, który został dopuszczony do badań klinicznych. W I fazie tych badań została określona maksymalna tolerowana dawka rekomendowana do dalszych badań w fazie II. Określono również profil działań ubocznych, pośród których są: hiperbilirubinemia, anemia, limfopenia, znużenie, anoreksja, zapalenie jamy ustnej, obrzęki, łysienie, nudności, biegunka, szumy w uszach, zapalenie żył w miejscu podania. Przyjmowanie leku powoduje również powstawanie bolesnych pęcherzy na skórze stóp i rąk [7], powiększenie śledziony oraz wpływa na pracę nerek [26], ze wzrostem poziomu kreatyniny oraz tkankowym uszkodzeniem kłębuszków i kanalików. Efekty toksyczności NAMI-A w pełni ustępują w ciągu 15-30 dni od zakończenia terapii. Wykazano również marginalną mutagenność związku [12]. Obecnie kompleks oczekuje na Il fazę badań klinicznych określającą efektywność jego zastosowania. Poddawany jest również testom pod kątem zastosowania w skojarzeniu z doksorubicyną w terapii raka piersi [27], a także trwają badania I/II fazy połączenia z gemcytabiną jako druga linia terapii w przerzutowym niedrobnokomórkowym raku płuca [28].

\section{KP1019}

KP1019 [(HIn) [trans-Ru $\left.{ }^{\text {III }} \mathrm{Cl}_{4}(\mathrm{In})_{2}\right]$, In-indazol (ryc. 4)] jest kompleksem Ru(III) zawierającym w sferze koordynacyjnej dwa heterocykliczne ligandy indazolowe oraz cztery jony chlorkowe.

Mechanizm działania KP1019 po podaniu dożylnym obejmuje rozkład kompleksu we krwi w wyniku hydrolizy, redukcję oraz reakcje z białkami osocza i innymi biologicznymi celami. Transport leku do komórki odbywa się poprzez białkowy transporter, jakim jest transferyna (HTF) i endocytozę układu HTF-kompleks, w której pośredniczą receptory błonowe dla tej proteiny. W komórce nowotworowej zachodzi uwolnienie kompleksu z endosomu na skutek wpływu pH, ATP i cytrynianów oraz jego redukcja do aktywnej formy $\mathrm{Ru}(\mathrm{II})$, która prowadzi do apoptozy komórek na ścieżce mitochondrialnej, generując reaktywne formy tlenu (ROS) [5, 29]. Pomimo tego, że mitochondrialna ścieżka jest odpowiedzialna za mitochondrialną depolaryzację membrany i aktywację apoptozy, oddziaływanie KP1019 z DNA nie może być wykluczone [5]. Omówiony schemat działania przedstawia rycina 5.

KP1019 ulega podobnym do cisplatyny interakcjom z DNA, jednak wiązania poprzeczne DNA-DNA i DNA-białko są około 15-krotnie słabsze od tych, które tworzy cisplaty- 


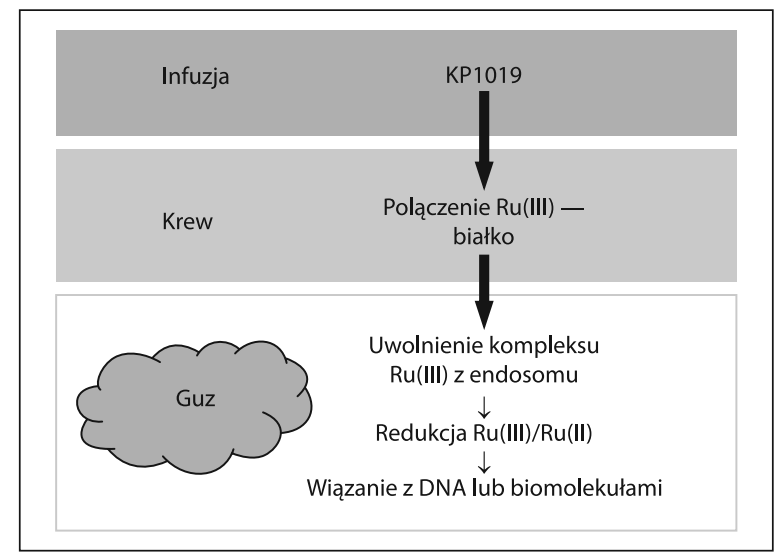

Rycina 5. Schemat działania KP1019 [6]

na. Redukcja KP1019 przez glutation i kwas askorbinowy wzmacniała pęknięcia nici w komórkach, w których efektywność tworzenia adduktów z DNA jest 6-krotnie niższa w porównaniu z cisplatyną. Cytotoksyczność związku w stosunku do linii komórkowych raka jelita grubego SW480, szyjki macicy KB-3-1 oraz sublinii wykazującej wielolekową oporność KBC-1 wzrastała wraz ze wzrostem stężenia kwasu askorbinowego, począwszy od stężenia $50 \mu \mathrm{M}$. Efekt chemoprotekcyjny pojawił się natomiast w obecności niewielkich ilości reduktora $(2,7-50 \mu \mathrm{M})$ tylko w przypadku linii SW480 [30]. Również zmiany konformacyjne indukowane w drugorzędowej strukturze DNA są mniejsze w porównaniu z tymi, które wywołuje lek platynowy (odpowiednio $6^{\circ}$ i $13^{\circ}$ ). Obecnie zakończyła się I faza badań klinicznych KP1019 i jego lepiej rozpuszczalnej soli sodowej KP1339. Badania te wykazały, że farmakokinetyka związków jest bardzo zbliżona do farmakokinetyki NAMI-A zarówno w odniesieniu do wiązania z białkami, jak również czasu półtrwania we krwi [5]. Przeprowadzone eksperymenty dowodzą również, że KP1019 oraz KP1339 wykazują duże powinowactwo do albuminy ludzkiego osocza (HSA) i łączą się z białkiem w obu jego miejscach wiążących (I i II miejsce wiązania wg Sudlowa). Ponadto te same badania pokazały, że oba kompleksy w warunkach fizjologicznych konkurują z bilirubiną o jej miejsce wiązania, co może mieć duże znaczenie w terapii pacjentów z dysfunkcją wątroby i podwyższonym poziomem bilirubiny [31]. Dodatkowo kombinowana terapia KP1339 z sorafenibem okazała się niezwykle aktywna, in vitro oraz in vivo, $\mathrm{w}$ stosunku do komórek nowotworu wątroby Hep3B. Leki te działają synergistycznie poprzez zatrzymanie cyklu w fazie $G_{2} / M$ i inhibicję aktywacji P38, ale również zwiększony wewnątrzkomórkowy wychwyt obu związków. Działanie takie pokazuje, że wystąpienie wewnętrznej oporności wielu komórek nowotworowych na kombinację sorafenib/KP1339 jest mało prawdopodobne i sugeruje dalszy rozwój kliniczny układu jako nowej strategii terapeutycznej nowotworów wątrobowokomórkowych i innych guzów litych [32, 33].

\section{Kompleksy arenowe Ru (II)}

Typową strukturę arenowych związków rutenu (II) typu "half-sandwich" o wzorze ogólnym $\left[\left(\eta^{6}\right.\right.$-aren) Ru(X)(Y)(Z)] przedstawia rycina 6. Zaobserwowano, że połączenie ligandów $Y$ i $Z$ w jeden dwufunkcyjny ligand $L$ wpływa znacząco na aktywność przeciwnowotworową kompleksów. Według badań istnieje zależność pomiędzy siłą działania związku a rozmiarem ligandów arenowych. Wzrost cytotoksyczności kompleksów zmienia się zgodnie z uszeregowanymi ligandami arenowymi: benzen < p-cymen < bifenyl < dihydroantracen $<$ tetrahydroantracen [34]. W testach wobec ko-

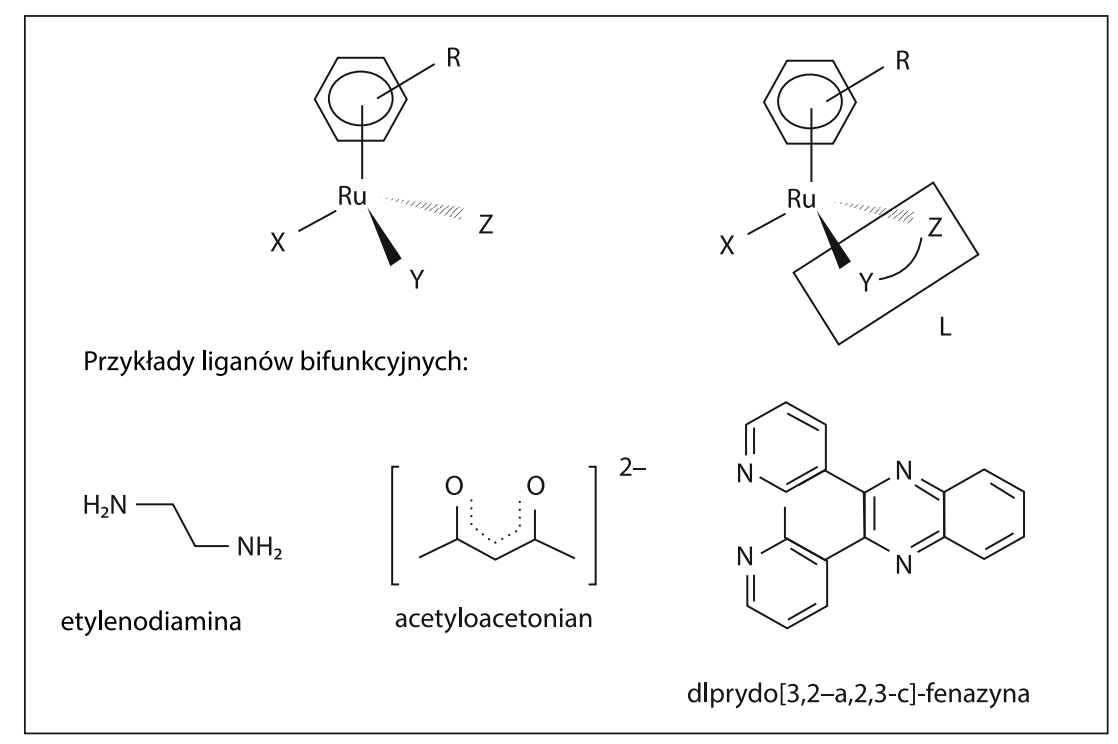

Rycina 6. Struktura kompleksów Ru(II) i wybranych ligandów [25] 


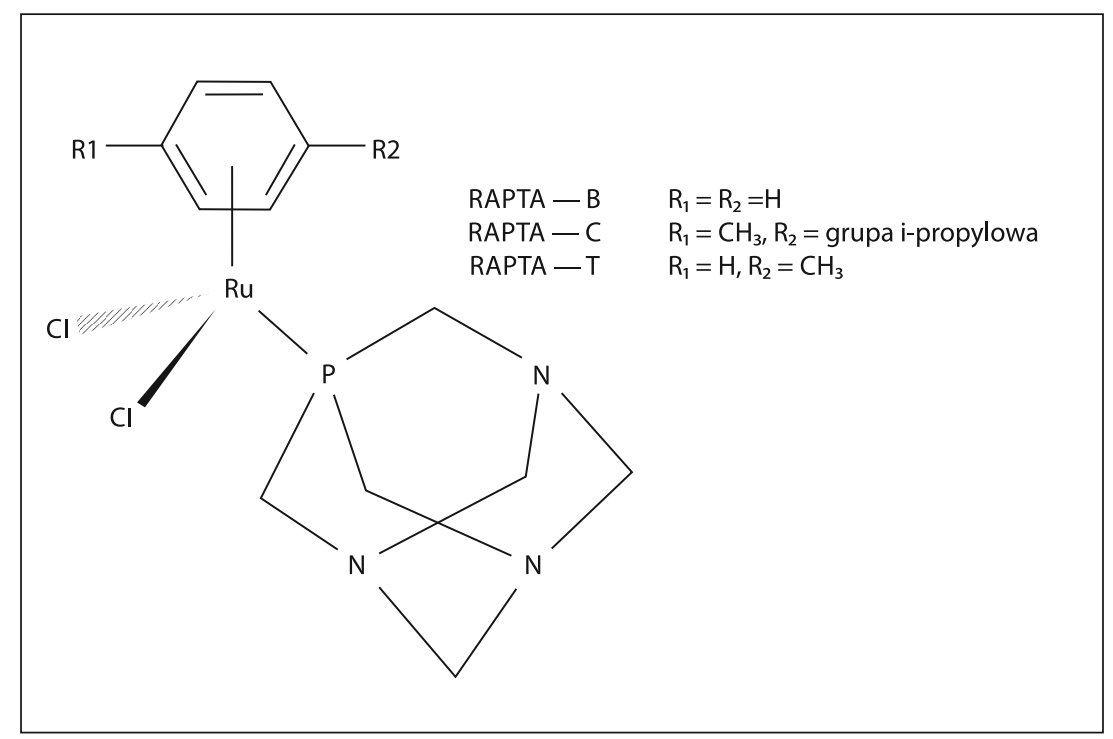

Rycina 7. Wzór strukturalny arenowych związków rutenu (II) z rodziny RAPTA

mórek ludzkiego raka jajnika cytotoksyczność kompleksów zawierających ligand diaminowy lub chlorkowy porównywalna jest do cisplatyny czy karboplatyny. Dodatkowo nie zauważono występowania krzyżowej oporności z cisplatyną. Największą aktywność posiadają związki zawierające przedłużone policykliczne ligandy arenowe i etylenodiaminę, natomiast polarne podstawniki w ligandzie arenowym obniżają znacząco cytotoksyczność [35].

Istotną cechą, która wpływa na cytotoksyczność związków arenowych $\mathrm{Ru}(\mathrm{II})$, jest ich zdolność wiązania z białkami i potencjalna aktywność katalityczna. Pod tym kątem prowadzono badania kompleksu - [( $\eta^{6}-p$-cymen $\left.) \mathrm{Ru}^{\prime \prime} \mathrm{Cl}_{2}\right]$, w których obserwowano jego wiązanie z lizozymem i stwierdzono, że miejscem addycji związku jest imidazol histydyny-15. Pochodne białkowe z przyłączonym ligandem mogą znaleźć zastosowanie w celu zwiększenia charakteru hydrofobowego i rozpuszczalności białek w niewodnych rozpuszczalnikach [36].

\section{RAPTA}

Kolejną grupą arenowych kompleksów Ru(II) wykazujących aktywność przeciwnowotworową są trzy związki, które tworzą tzw. grupę RAPTA. Kompleksy te zawierają w swym składzie ligand fosfinowy - 1,3,5-triaza-fosfaadamantan (PTA) (ryc. 7). Liczne badania in vitro nad szeregiem RAPTA ze zmodyfikowanymi ligandami arenowymi wykazały, że są one słabo toksyczne w stosunku do komórek nowotworowych i całkowicie nie wykazują działania cytotoksycznego w kierunku komórek zdrowych [10].

W badaniach in vitro związek RAPTA-T powodował inhibicję niektórych kroków na drodze procesu przerzutowania, takich jak oderwanie komórek inicjujących przerzuty od masy guza zasadniczego, migracja i naciekanie, re-adhezja.
Aktywność przeciwprzerzutową łączy się z interakcjami $z$ komponentami matrix. In vivo RAPTA-T selektywnie redukuje masę i rozrost przerzutów nowotworowych do płuc i wykazuje tylko niewielką, łagodną aktywność w stosunku do nowotworu pierwotnego [37]. Zaobserwowano, że RAPTA-T tworzy wiązanie $z$ helisą DNA zależne od pH, co sugeruje mechanizm aktywacji poprzez protonację. Kolejne badania z aktywowanym protonacją kompleksem wykazały równoczesną toksyczność w kierunku komórek nowotworowych oraz zdrowych. Liczne modyfikacje ligandów w grupie dowiodły, że ligand fosfinowy odpowiada za selektywną aktywność związków [10].

Następny z tej grupy kompleks, RAPTA-C, in vivo wykazuje działanie antymetastatyczne [38], jak również o ok. 75\% hamuje wzrost pierwotnego guza jajnika A2780 z inhibicją angiogenezy częściowo odpowiedzialnej za ten proces. Ponadto związek jest szybko usuwany z organów i krwiobiegu, co czyni go niezwykle atrakcyjnym jako potencjalny lek przeciwnowotworowy [39]. Badania nad molekularnym mechanizmem działania RAPTA-C wykazały, że cząsteczka hamuje efektywnie wzrost komórki poprzez wstrzymanie cyklu w fazie $G_{2} / M$ i apoptozy. Zatrzymanie cyklu komórkowego jest związane ze zwiększonym poziomem p21 i zredukowaną ilością cykliny E. Działanie RAPTA-C podnosi również poziom p53, wyzwalając mitochondrialny szlak apoptozy, oraz wzmaga aktywność głównego mediatora inhibicji wzrostu komórek JNK, przez który działa [40].

Wydaje się być ciekawe, że dwa tak odmienne strukturalnie związki - NAMI-A (koordynacyjny kompleks Ru(III)) i RAPTA-T (metaloorganiczny związek Ru(II)) wykazują podobną aktywność przeciwnowotworową, będąc nieaktywne w kierunku zasadniczego guza, ale aktywne w stosunku do przerzutów. Oba związki wykazują bardzo niską systemową 


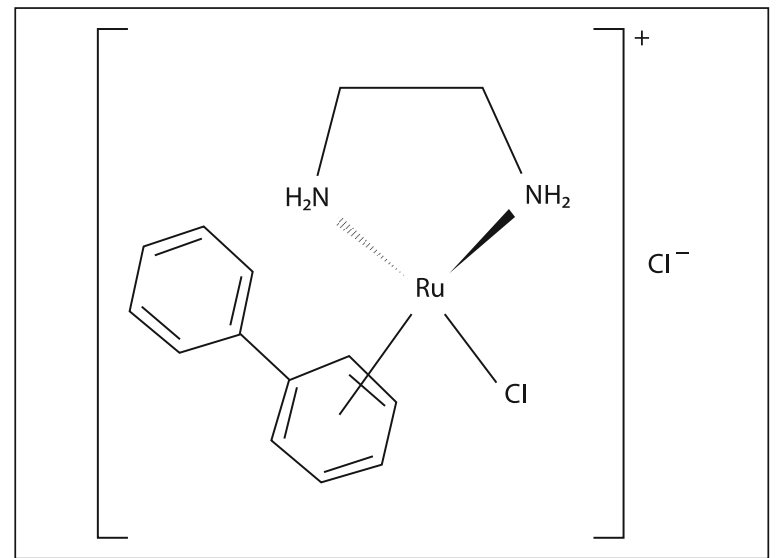

Rycina 8. Wzór strukturalny ONCO4417

toksyczność, co czyni je wysoce atrakcyjnymi lekami w przyszłej farmakoterapii [10].

\section{RM175 (ONCO4417)}

ONCO4417 jest metaloorganicznym kompleksem rutenu(II), w którym występuje bezpośrednie wiązanie metal-węgiel (ryc. 8). Z racji stopnia utlenienia metalu (+2) związek ten łamie regułę „aktywacji przez redukcję”. Aktywność przeciwnowotworowa ONCO4417 wynika z możliwości tworzenia wiązań z guaninami DNA, jak również oddziaływania na drodze interkalacji. Badania wykazały [29, 41], że kompleksy zawierające w swym składzie aromatyczne ligandy dwupierścieniowe wywołują większe uszkodzenia DNA w stosunku do tych, które posiadają jeden pierścień aromatyczny. Oddziaływanie związków zawierających bifenyl, dihydroantracen lub tetrahydroantracen z DNA obejmuje tworzenie wiązań koordynacyjnych z guaniną i niekowalencyjne, hydrofobowe oddziaływania stackingowe pomiędzy ligandem arenowym i zasadami nukleinowymi, jak również wiązanie w mniejszym rowku DNA. Addukty arenowych kompleksów Ru(II) są preferencyjnie usuwane z DNA przez mechanizmy inne niż naprawa przez wycinanie nukleotydu, co sprawia, że aktywność przeciwnowotworowa tej grupy związków różni się od aktywności cisplatyny. ONCO4417 wywołuje apoptozę komórek nowotworowych oraz powoduje zatrzymanie cyklu komórkowego w fazie $\mathrm{G}_{2} / \mathrm{M}$ [42]. Dodatkowo powoduje zniekształcenia helisy DNA w stopniu podobnym do cisplatyny, tworząc preferencyjne wiązania $\mathrm{z}$ atomem azotu $\mathrm{N}_{7}$ guaniny [34]. W badaniach in vitro zaobserwowano aktywność ONCO4417 w stosunku do komórek raka jajnika, płuc, przełyku, trzustki, jelita grubego oraz czerniaka. Co więcej, ONCO4417 zachowuje przeciwnowotworową aktywność również wobec linii komórkowych nowotworów jajnika opornych na cisplatynę, co potwierdza hipotezę odmiennego mechanizmu działania i braku wspólnego schematu tworzenia odporności krzyżowej z cisplatyną. Ponadto związek ten wykazywał in vivo aktywność w stosunku do linii komórek nowotworu piersi MCa i powodował redukcję przerzutów [43].

\section{Kierunki rozwoju chemoterapeutyków opartych na związkach rutenu Nieklasyczne cele działania chemoterapeutyków}

Najnowsze podejścia terapeutyczne w dziedzinie tworzenia nowych metod leczenia nowotworów skupiają się na kontroli produktów transkrypcji genów i w szczególności jest to kontrola szlaków sygnałowych charakterystycznych dla komórek nowotworowych. Aktywność tych szlaków może być całkowicie specyficzna dla komórek rakowych i w żadnym aspekcie nie dotyczy komórek w stanie fizjologicznym. Atrakcyjnym celem z punktu proteomiki komórek rakowych są szlaki kinaz, które stanowią bazę do syntezy nowych, selektywnych leków przeciwnowotworowych [25].

Jedną z najbardziej obiecujących właściwości nowo zsyntetyzowanych kompleksów rutenu jest ich zdolność do upodabniania się do organicznych inhibitorów enzymów. Zaobserwowano, że naturalny związek z grupy alkaloidów - saturosporyna (rycina 9 wzór 1) - jest bardzo silnym inhibitorem dla licznej grupy kinaz. Struktura saturosporyny posłużyła do syntezy metaloorganicznego, oktaedrycznego

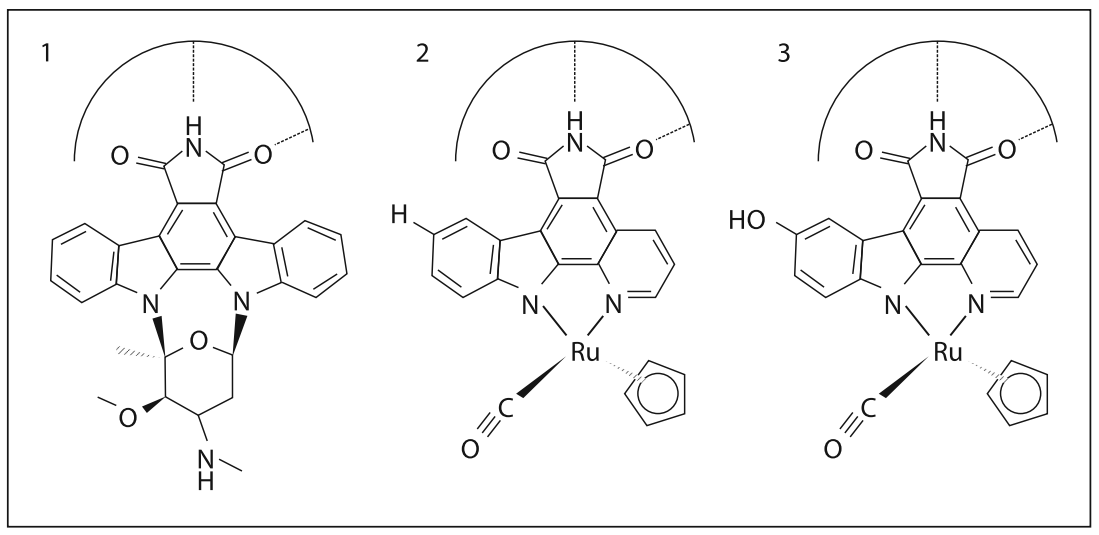

Rycina 9. Wzór strukturalny staurosporyny (1), rutenowej pochodnej (2) i DW1/2 (3) [23] 


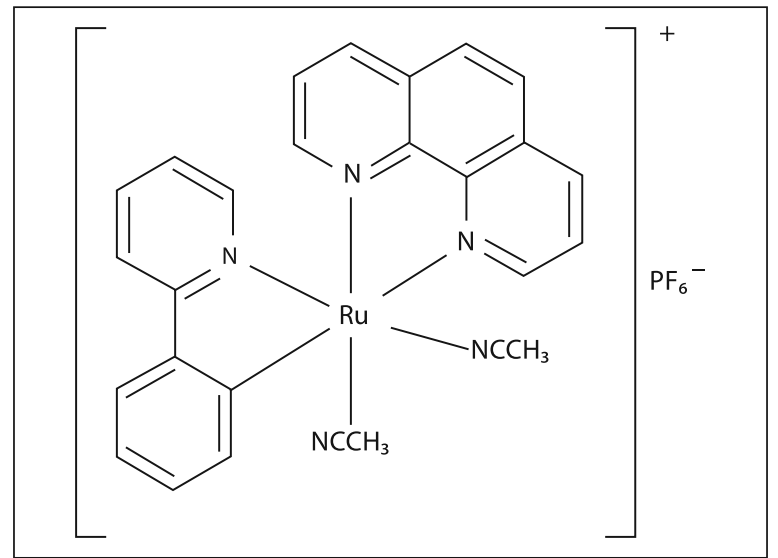

Rycina 10. Wzór strukturalny RDC-11

kompleksu rutenu (rycina 9 wzór 2), który podobnie jak ligand, działa jako inhibitor kinaz białkowych. Badania wykazały, że związek ten jest selektywnym oraz konkurencyjnym w stosunku do ATP inhibitorem kinazy syntazy glikogenu (GSK-3). Warto podkreślić, że otrzymany kompleks rutenu wykazuje znacznie większe powinowactwo i selektywność działania w porównaniu z wzorcową staurosporyną. Kolejne badania ujawniły, że minimalna modyfikacja w strukturze omawianego kompleksu polegająca na wprowadzeniu do cząsteczki indolu grupy hydroksylowej skutkuje zwiększeniem powinowactwa związku do GSK-3. Korzystniejsze właściwości zsyntetyzowanego związku DW1/2 (rycina 9 wzór 3) wynikają z lepszej interakcji z miejscem wiązania ATP. Otrzymany związek DW1/2 jest rozpuszczalnym w wodzie, specyficznym i wysoce selektywnym inhibitorem zdolnym modulować komórkowe ścieżki sygnałowe [25] i działa poprzez ukierunkowaną aktywność wobec białek zamiast DNA. Udowodniono, że DW1/2 aktywuje p53 i indukuje tym samym apoptozę poprzez szlak mitochondrialny w wysoce chemoodpornych komórkach czerniaka [44]. Mechanizm aktywności DW1/2 wydaje się stanowić podstawę powodzenia w leczeniu nowotworów, w których proliferację moduluje GSK-3. Przykładem może być nowotwór trzustki, gdzie inhibicja GSK-3 $\beta$ prowadzi do zmniejszenia proliferacji komórek nowotworu i wpływa na obniżenie aktywności mediatorów transkrypcji genów [25].

Kolejny związek — RDC11 (ryc. 10) - wykazuje aktywność przeciwnowotworową w stosunku do komórek odpornych na działanie cisplatyny, a przy tym charakteryzuje się mniejszą niż cisplatyna toksycznością. W stosunku do związku referencyjnego wykazywał niższą nefrotoksyczność, neurotoksyczność oraz hepatotoksyczność. Badania in vitro dowiodły, że RDC1 1 w dużo mniejszym stopniu niż cisplatyna prowadzi do uszkodzenia DNA, co wskazuje, że inne ścieżki komórkowe odpowiadają za efekt przeciwnowotworowy tego związku. Najprawdopodobniej aktywność ta wynika z indukcji ekspresji kilku genów na ścieżce stresu retikulum endoplazmatycznego, Bip, Xbp1, Pdi oraz Chop, wśród których Chop odgrywa najistotniejszą rolę dla cytotoksyczności RDC11. Aktywacja transkrypcji Chop prowadzi do ekspresji dwóch jego proapoptotycznych genów - Chac1 oraz Trb3. Wyciszenie Chop znacznie redukowało cytotoksyczność związku, podczas gdy nadekspresja wzmagała proces apoptozy komórki po ekspozycji na kompleks rutenu. Badanie to dowodzi, że gen ten jest niezbędny dla uzyskania efektu przeciwnowotworowego RDC11 [45].

\section{Ruten jako podstawa tworzenia zwiq̨zów o konstrukcji trójwymiarowej}

Kompleksy metali dają wiele możliwości w tworzeniu nowych chemoterapeutyków. Potencjał wielkiej różnorodności związków opartych na metalach zapewnia szereg zmiennych, takich jak rodzaj metalu, swoiste właściwości kationów i ligandów, stopień utlenienia jonu centralnego, ilość i rodzaj ligandów, szeroki zakres liczb koordynacji i geometrii związku. Jony metali włączane są do potencjalnych leków przeciwnowotworowych ze względu na ich reaktywność i cytotoksyczność. Obecnie są one również wykorzystywane jako podstawa tworzenia dobrze zdefiniowanych, trójwymiarowych konstrukcji. Podejście to pozwala na syntezę związków o strukturze z unikalną stechiometrią i orientacją organicznych ligandów, wykorzystując dostępność różnych geometrii kompleksów metali. W ten sposób otrzymano konstrukcje niedostępne dla czysto organicznych związków, jednak ze względu na kinetyczną inercję wiązań koordynacyjnych w zasadzie zachowują się one jak związki organiczne [46].

W kompleksie rutenu DW1/2 metal stanowi centrum, wokół którego zorganizowane są ligandy organiczne w przestrzeni trójwymiarowej tak, aby zapewniały dostęp do miejsc działania nie zawsze dostępnych dla struktur czysto organicznych. Interakcja DW1/2 z białkową kinazą Pim-1 zachodzi zgodnie z modelem typowym dla wiązania inhibitorów organicznych tego enzymu. W DW1/2 centrum metaliczne nie jest zaangażowane $w$ bezpośrednie wiązanie w miejscu aktywnym enzymu. Metal decyduje o orientacji ligandów w przestrzeni receptora, stwarza strukturę trójwymiarową komplementarną kształtem i obecnością grup funkcyjnych z miejscem wiązania w Pim-1. Pim-1 jest protoonkogenem rodziny kinaz serynowo-treoninowych nadekspresjonowanych w wielu typach ciężkich białaczek ludzkich. Ekspresja tego enzymu wiąże się ze wzrostem indukcji mitozy i zwiększeniem przeżycia komórek niezależnie od stymulacji czynnika wzrostu. Dodatkowo działa on synergistycznie z c-Myc w wywoływaniu białaczki oraz jednocześnie zwiększa aktywność transkrypcyjną komórkowego czynnika proliferacji c-Myc [47]. Inhibicja Pim-1 poprzez DW1/2 stanowi nową koncepcję terapii nowotworów, w szczególności włączając nowotwory oporne na małocząsteczkowe inhibitory kinazy tyrozynowej [48]. 


\section{Nanotechnologia kompleksów rutenu}

W celu uzyskania lepszych efektów terapii wielu jednostek chorobowych coraz częściej stosowane są nowe podejścia zastępujące konwencjonalne schematy leczenia. Jednym z najnowszych i najbardziej obiecujących, szczególnie w onkologii, jest wykorzystanie nanotechnologii jako systemu dostarczania leków. Systemy te - w porównaniu z klasyczną chemioterapią — charakteryzuje dłuższy okres półtrwania, korzystniejsza biodystrybucja leku i zredukowane efekty uboczne kuracji. Podstawowe nanosystemy obejmują systemy nieorganiczne (węglowe nanorurki, nanocząstki złota, nanocząstki koloidowe), polimery (dendrymery, micele, liposomy) oraz nośniki hybrydowe. Micele polimerowe są amfifilowymi sferycznymi strukturami złożonymi z hydrofobowego rdzenia, który przechowuje lek i hydrofilowej muszli, która stabilizuje micelę w środowisku wodnym. Zatem polimerowe micele są wysoce stabilne, biokompatybilne i odpowiednie do dostarczania i kontrolowanego uwalniania leku.

Ze względu na wysoką aktywność przeciwnowotworową, doskonałe właściwości antymetastatyczne oraz małe efekty uboczne związki koordynacyjne rutenu należą do jednych z najbardziej obiecujących, potencjalnych leków przeciwnowotworowych na bazie metalu. Jednak ich kliniczne zastosowanie jest hamowane ze względu na ograniczoną rozpuszczalność oraz stabilność w warunkach fizjologicznych. W celu ominięcia powyższych problemów na kompleksach rutenu znajdujących się w badaniach klinicznych testowane są strategie wykorzystujące techniki nanotechnologiczne. Zastosowanie syntetycznych polimerowych miceli [49] lub polilaktydu z surfaktantem Twin 80 [50] jako systemów dostarczania leku pozwala przełamać problem szybkiej hydrolizy KP1019, jak również oporności wybranych komórek nowotworowych na ten związek. Polilaktyd po wprowadzeniu do organizmu ulega hydrolizie i rozkładowi do kwasu mlekowego, który występuje naturalnie jako produkt metabolizmu. W związku z tym zastosowanie jego polimeru jako nośnika leku nie wiąże się z ryzykiem systemowej toksyczności [51]. Ponadto omawiany kompleks rutenu wykazuje bardzo duże powinowactwo do albuminy osocza (HSA), co stanowi dość poważny problem podczas farmakoterapii. Wprowadzenie związku do PeGylowanych polimerowych miceli, a następnie inkubacja powstałego układu MC-KP1019 z białkiem nie wykazały utworzenia adduktów MC-KP1019-HSA. Wypełnienie miceli związkiem rutenu spowodowało również wzrost aktywności przeciwnowotworowej kompleksu oraz przełamało oporność komórek nowotworowych na lek w stanie wolnym. Szczególnie korzystne efekty zostały osiągnięte w przypadku linii komórkowych niedrobnokomórkowego raka płuc (SW1573/2R160, SW1573/2R120) oraz nowotworu piersi (MCF-7/adr). Aktywność leku w tych przypadkach wzrosła odpowiednio 18.9-, 22.7- i 13.0-krotnie. Wzrost aktywności związku w wyniku nanoformulacji wynika z jego większej efektywności i zdolności deformacji DNA [49]. Podobne rezultaty dały badania nanoukładów KP1019-polilaktyd-TWIN80 (TWNP). Osadzenie leku na nośniku spowodowało wzrost jego aktywności przeciwnowotworowej 20-krotnie w stosunku do linii komórek raka jelita grubego (SW480) oraz wątroby (Hep3B) [50]. Śmierć komórek po ekspozycji na TWNP następuje w ciągu kilku godzin, co świadczy o zaangażowaniu $w$ ten proces reaktywnych form tlenu (ROS) i generowaniu przez TWNP wzmożonego poziomu stresu oksydacyjnego, który jest odpowiedzialny za wysoką cytotoksyczność TWNP.

Ponadto na bazie NAMI-A powstała seria lipidowych związków rutenu, które $w$ badaniach in vitro - w porównaniu ze związkiem macierzystym - wykazywały dużo korzystniejszy profil biologiczny. Charakteryzowały się wyższą aktywnością antyproliferacyjną, stabilnością w warunkach fizjologicznych oraz wychwytem komórkowym [52,53].

Zastosowanie nanoformulacji stanowi doskonałe narzędzie do modyfikacji stabilności i aktywności przeciwnowotworowej KP1019 w warunkach fizjologicznych. Obecnie trwają badania in vivo nad tolerancją i efektami celowanej terapii nowych nanoukładów KP1019.

\section{Kompleksy rutenu w terapii choroby Alzhaimera i wirusa HIV}

Szeroko zakrojone badania nad aktywnością biologiczną związków rutenu doprowadziły do postawienia hipotezy, że kompleksy te oprócz doskonałych właściwości przeciwnowotworowych mogą wykazywać również skuteczność w terapii innych schorzeń, m.in. choroby Alzheimera czy zakażeń wirusem HIV. Przeprowadzone doświadczenia pokazały, że nowy kompleks rutenu(III) PMRU20 [(2-aminotiazol[trans-tetrachlorobis(2-aminotiazol)-ruten(III)] wykazuje in vitro doskonałe właściwości neuroprotekcyjne [54]. Poziom protekcji hodowli neuronów korowych jest porównywalny z tym, jaki wykazują klasyczne związki organiczne [55] stosowane obecnie w leczeniu choroby Alzheimera. Ponadto związek ten nie wykazuje in vitro istotnej toksyczności. Wstępnie określona aktywność biologiczna PMRU20 została przypisana jego zdolności inhibicji agregacji $\beta$-amyloidu i zapobiegania tworzeniu oligomeru najprawdopodobniej jako wynik bezpośredniej i ścisłej interakcji z peptydem $A \beta$. Badania techniką ESI-MS wykazały, że w wyniku tego oddziaływania powstaje stabilny „niekowalencyjny” addukt pomiędzy kompleksem a A 1 1-42. Porównanie aktywności PMRU20 z NAMI-A i KP1019 dowiodło, że te 2 ostatnie związki nie wykazują najmniejszej aktywności neuroprotekcyjnej [54].

Ponadto badaniom biologicznym poddano dwa kompleksy rutenu o wzorze ogólnym [RuCl(n6-p-cymen)L] z pochodnymi elwitegrawiru i raltegrawiru (ligand L) — inhibitorów integrazy, leków przeciwwirusowych stosowanych 
w leczeniu dorosłych zarażonych wirusem HIV. Okazało się, że związki te jako jedyne kompleksy metali wykazują wysoką aktywność w stosunku do integrazy HIV. Aktywność kompleksu z pochodną elwitegrawiru wynikała z częściowej hydrolizy związku z odłączeniem tego liganda. Z drugiej strony kompleks z pochodną raltegrawiru jest bardzo stabilny w roztworze wodnym, a pomimo to wykazywał wyższą aktywność w stosunku do integrazy HIV niż jego analog z elwitegrawirem. Niemniej jednak najprawdopodobniej wysoka aktywność i inhibicja integrazy HIV-1 przez oba związki wynika z możliwości przenoszenia liganda w miejsce aktywne enzymu, gdzie może on interferować z kofaktorami magnezu [56].

Przeprowadzone wstępnie badania wykazują, że związki koordynacyjne rutenu w przyszłości mogą zostać wykorzystane w nowych strategiach leczenia chorób neurodegeneracyjnych i wirusów, w szczególności wirusa HIV, który ze względu na szybkie mutacje i namnażanie utrudnia skuteczną terapię.

\section{Podsumowanie}

Sukces kliniczny cisplatyny doprowadził do szybkiego rozwoju badań nad innymi związkami metali mogących stanowić nowe, potencjalne leki przeciwnowotworowe. Na fali tych badań zsyntetyzowanych zostało kilka kompleksów rutenu, które ze względu na unikalne właściwości biochemiczne, selektywne działanie w obrębie komórek nowotworowych i mniejszą toksyczność w stosunku do komórek prawidłowych stanowią grupę leków drugiej generacji (po kompleksach platyny) opartych na metalu. Zarówno kompleksy rutenu(II), jak i rutenu(III) wykazują aktywność przeciwnowotworową w stosunku do wielu linii komórek nowotworowych i modeli zwierzęcych. Omówione w powyższym przeglądzie związki są aktywne w stosunku do guzów pierwotnych lub działają głównie poprzez inhibicję procesów metastazy. Dwa najbardziej obiecujące kompleksy rutenu(III) (NAMI-A i KP1019) z powodzeniem zakończyły I fazę badań klinicznych.

Niemniej jednak zaawansowanie badań nad przeciwnowotworowym potencjałem związków rutenu jest mniejsze w porównaniu z kompleksami platyny. Obecnie nie jest możliwe również jednoznaczne określenie mechanizmu działania oraz zakresu aktywności biologicznej tych środków. Zdobyta dotychczas wiedza stanowi ważne narzędzie w dalszych badaniach mechanizmu działania związków rutenu, który różni się od mechanizmu cisplatyny i jej analogów. Kompleksy omówione w opracowaniu, różniące się strukturą i stopniem utlenienia metalu oraz wykazujące różną aktywność biologiczną, są tylko częścią ogromnych możliwości tworzenia nowych medykamentów. Przyszłość kompleksów rutenu jako leków i kandydatów do kolejnych badań klinicznych wciąż pozostaje wyzwaniem i daje dużą nadzieję na opracowanie skutecznych terapii wielu schorzeń.

Konflikt interesów: nie zgłoszono

\section{Dr Urszula Śliwińska-Hill}

Uniwersytet Medyczny im. Piastów Śląskich

Katedra i Zakład Chemii Analitycznej

ul. Borowska 211A, 50-566 Wrocław

e-mail:urszula.sliwinska-hill@umed.wroc.pl

Otrzymano: 30 marca 2015 r.

Przyjęto do druku: 28 lipca 2015 r.

\section{Piśmiennictwo}

1. Antonarakis ES, Emadi A, Ruthenium-based chemotherapeutics: are they ready for prime time? Cancer Chemother Pharmacol 2010; 66: 1-9.

2. Reisner E, Arion VB, Keppler BK i wsp. Electron-transfer activated metal-based anticancer drugs. Inorg Chim Acta 2008; 361: 1569-1583.

3. Kratz F, Messori L, Spectral characterization of ruthenium (III) transferrin JInorg Biochem 1993; 49: 79-82.

4. Sava G, Bergamo A, Ruthenium-based compounds and tumour growth control (review). Int J Oncol 2000; 17: 353-365.

5. Hartinger CG, Zorbas-Seifried S, Jakupec MA i wsp. From bench to bedside - preclinical and early clinical development of the anticancer agent indazolium trans-tetrachlorobis(1H-indazole)ruthenate(III) (KP1019 or FFC14A). J Inorg Biochem 2006; 100: 891-904.

6. Boerner LJ, Zaleski JM, Metal complex-DNA interactions: from transcription inhibition to photoactivated cleavage. Curr Opin Chem Biol 2005; 9: 135-144.

7. Rademaker-Lakhai JM, van den Bongard D, Pluim D i wsp. A Phase I and pharmacological study with imidazolium-trans-DMSO-imidazole-tetrachlororuthenate, a novel ruthenium anticancer agent. Clin Cancer Res 2004; 10: 3717-3727.

8. Brouwers EE, Tibben MM, Rosing $\mathrm{H}$ i wsp. Determination of ruthenium originating from the investigational anti-cancer drug NAMI-A in human plasma ultrafiltrate, plasma, and urine by inductively coupled plasma mass spectrometry. Rapid Commun Mass Spectrom 2007; 21: $1521-1530$.

9. Graf N, Lippard SJ, Redox activation of metal-based prodrugs as a strategy for drug delivery. Adv Drug Delivery Rev 2012; 64: 993-1004.

10. Dyson PJ, Sava G, Metal-based antitumour drugs in the post genomic era. Dalton Trans 2006; 1929-1933.

11. Pillozzi S, Gasparoli L, Stefanini M i wsp. NAMI-A is highly cytotoxic toward leukaemia cell lines: Evidence of inhibition of KCa 3.1 channels. Dalton Trans 2014; 32: 12150-12155.

12. Bergamo A, Gaiddon C, Schellens JH i wsp. Approaching tumour therapy beyond platinum drugs. Status of the art and perspectives of ruthenium drug candidates. J Inorg Biochem 2012; 106: 90-99.

13. Sava G, Frausin F, Cocchietto M i wsp. Actin-dependent tumour cell adhesion after short-term exposure to the antimetastasis ruthenium complex NAMI-A. Eur J Cancer 2004; 40: 1383-1396.

14. Frausin F, Scarcia V, Cocchietto M i wsp. Free exchange across cells, and echistatin-sensitive membrane target for the metastasis inhibitor NAMI-A (Imidazolium trans-Imidazole Dimethyl Sulfoxide Tetrachlororuthenate) on KB tumor cells. J Pharmacol Exp Ther 2005; 313: 227-233.

15. Gava B, Zorzet S, Spessotto P i wsp. Inhibition of B16 melanoma metastases with the ruthenium complex Imidazolium trans-Imidazoledimethylsulfoxide-tetrachlororuthenate and down-regulation of tumor cell invasion. J Pharmacol Exp Ther 2006; 317: 284-291.

16. Pintus G, Tadolini B, Posadino AM i wsp. Inhibition of the MEK/ERK signaling pathway by the novel antimetastatic agent NAMI-A down regulates c-myc gene expression and endothelial cell proliferation. Eur J Biochem 2002; 269: 5861-5870.

17. Debidda M, Sanna B, Cossu A i wsp. NAMI-A inhibits the PMA-induced ODC gene expression in ECV304 cells: Involvement of PKC/Raf/Mek/ERK signalling pathway. Int J Oncol 2003; 23: 477-482.

18. Vacca A, Bruno $M$, Boccarelli $A$ i wsp. Inhibition of endothelial cell functions and of angiogenesis by the metastasis inhibitor NAMI-A. Br J Cancer 2002; 86: 993-998. 
19. Morbidelli L, Donnini S, Filippi S i wsp. Antiangiogenic properties of selected ruthenium(III) complexes that are nitric oxide scavengers. Br J Cancer 2003; 88: 1481-1491.

20. Magnarin M, Bergamo A, Carotenuto ME i wsp. Increase of tumour infiltrating lymphocytes in mice treated with antimetastatic doses of NAMI-A. Anticancer Res 2000; 20: 2939-2944.

21. Pacor S, Zorzet S, Cocchietto M i wsp. Intratumoral NAMI-A treatment triggers metastasis reduction, which correlates to $C D 44$ regulation and tumor infiltrating lymphocyte recruitment. $J$ Pharmacol Exp Ther 2004; 310: 737-744.

22. Sava G, Zorzet S, Turrin C i wsp. Dual action of NAMI-A in inhibition of solid tumor metastasis: selective targeting of metastatic cells and binding to collagen. Clin Cancer Res 2003; 9: 1898-1905.

23. Pacor $\mathrm{S}$, Vadori M, Vita F i wsp. Isolation of a murine metastatic cell line and preliminary test of sensitivity to the antimetastasis agent NAMI-A. Anticancer Res 2001; 21: 2523-2530.

24. Zhang CX, Lippard SJ. New metal complexes as potential therapeutics. Curr Opin Chem Biol 2003; 7: 481-489.

25. Bergamo A, Sava G, Ruthenium complexes can target determinants of tumour malignancy. Dalton Trans 2007; 7: 1267-1272.

26. Vadori M, Pacor S, Vita F i wsp. Features and full reversibility of the renal toxicity of the ruthenium-based drug NAMI-A in mice. J Inorg Biochem 2013; 118: 21-27.

27. Bergamo A, Riedel T, Dyson PJ i wsp. Preclinical combination therapy of the investigational drug NAMI-A(+) with doxorubicin for mammary cancer. Invest New Drugs 2015; 33: 53-63.

28. Leijen S, Burgers SA, Baas P i wsp. Phase $1 /$ II study with ruthenium compound NAMI-A and gemcitabine in patients with non-small cell lung cancer after first line therapy. Invest New Drugs 2015; 33: 201-214.

29. Piccioli F, Sabatini S, Messori L i wsp. A comparative study of adduct formation between the anticancer ruthenium(III) compound HInd trans-RuCl4(Ind)2 and serum proteins. J Inorg Biochem 2004; 98: 1135-1142.

30. Bartel C, Egger AE, Jakupec MA i wsp. Influence of ascorbic acid on the activity of the investigational anticancer drug KP1019. J Biol Inorg Chem 2011; 16: 1205-1215.

31. Domotor O, Hartinger CG, Bytzek AK i wsp. Characterization of the binding sites of the anticancer ruthenium(III) complexes KP1019 and KP1339 on human serum albumin via competition studies. J Biol Inorg Chem 2013; 18: 9-17.

32. Heffeter $\mathrm{P}$, Atil B, Kryeziu K i wsp. The ruthenium compound KP1339 potentiates the anticancer activity of sorafenib in vitro and in vivo. Eur J Cancer 2013; 49: 3366-3375.

33. Trondl R, Heffeter P, Kowol CR i wsp. NKP-1339, the first ruthenium-based anticancer drug on the edge to clinical application. Chem Sci 2014; 5: 2925-2932.

34. Yan YK, Melchart M, Habtemariam A i wsp. Organometallic chemistry, biology and medicine: ruthenium arene anticancer complexes. Chem Commun 2005; 4764-4776.

35. Habtemariam A, Melchart M, Fernandez R i wsp. Structure-activity relationships for cytotoxic ruthenium(II) arene complexes containing $\mathrm{N}, \mathrm{N}-, \mathrm{N}, \mathrm{O}-$, and O,O-chelating ligands. J Med Chem 2006; 49: 6858-6868.

36. McNae IW, Fishburne K, Habtemariam A i wsp. Half-sandwich arene ruthenium(II)-enzyme complex. Chem Commun 2004; 1786-1787.

37. Bergamo A, Masi A, Dyson PJ i wsp. Modulation of the metastatic progression of breast cancer with an organometallic ruthenium compound. Int J Oncol 2008; 33: 1281-1289.

38. Nowak-Sliwinska P, van Beijnum JR, Casini A i wsp. Organometallic ruthenium(II) arene compounds with antiangiogenic activity. J Med Chem 2011; 54: 3895-3902.
39. Weiss A, Berndsen RH, Dubois M i wsp. In vivo anti-tumor activity of the organometallic ruthenium(II)-arene complex Ru(n-6-p-cymene)$\mathrm{Cl} 2$ (pta). (RAPTA-C) in human ovarian and colorectal carcinomas. Chem Sci 2014; 5: 4742-4748.

40. Chatterjee $S$, Kundu S, Bhattacharyya A i wsp. The ruthenium(II)-arene compound RAPTA-C induces apoptosis in EAC cells through mitochondrial and p53-JNK pathways. J Biol Inorg Chem 2008; 13: 1149-1155.

41. Schluga $P$, Hartinger CG, Egger A i wsp. Redox behavior of tumor-inhibiting ruthenium(III) complexes and effects of physiological reductants on their binding to GMP. Dalton Trans 2006; 14: 1796-1802.

42. Aird RE, Cummings J, Ritchie AA i wsp. In vitro and in vivo activity and cross resistance profiles of novel ruthenium (II) organometallic arene complexes in human ovarian cancer. Br J Cancer 2002; 86: 1652-1657.

43. Reisner E, Arion VB, Guedes da Silva MFC i wsp. Tuning of redox potentials for the design of ruthenium anticancer drugs-an electrochemical study of [trans-RuCl(4)L(DMSO)](-) and [trans-RuCl(4)L(2)(-) complexes, where $L=$ imidazole,1,2,4-triazole, indazole. Inorg Chem 2004; 43: 7083-7093.

44. Smalley KS, Contractor R, Haass NK i wsp. An organometallic protein kinase inhibitor pharmacologically activates $\mathrm{p} 53$ and induces apoptosis in human melanoma cells. Cancer Res 2007; 67: 209-217.

45. Meng $X$, Lewa ML, Jenny $M$ i wsp. Ruthenium-containing organometallic compound reduces tumor growth through induction of the endoplasmic reticulum stress gene CHOP. Cancer Res 2009; 69: 5458$-5466$.

46. Bruijnincx PC, Sadler PJ. New trends for metal complexes with anticancer activity. Curr Opin Chem Biol 2008; 12: 197-206.

47. Kim KT, Baird K, Ahn JY i wsp. Pim-1 is up-regulated by constitutively activated FLT3 and plays a role in FLT3-mediated cell survival. Blood 2005; 105: 1759-1767.

48. Adam M, Pogacic V, Bendit M i wsp. Targeting PIM kinases impairs survival of hematopoietic cells transformed by kinase inhibitor-sensitive and kinase inhibitor-resistant forms of Fms-like tyrosine kinase 3 and BCR/ABL. Cancer Res 2006; 66: 3828-3835.

49. Heffeter P, Riabtseva A, Senkiv Y i wsp. Nanoformulation improves activity of the (pre)clinical anticancer ruthenium complex KP1019. J Biomed Nanotechnol 2014; 10: 877-884.

50. Fischer B, Heffeter P, Kryeziu K i wsp. Poly(lactic acid) nanoparticles of the lead anticancer ruthenium compound KP1019 and its surfactant-mediated activation. Dalton Trans 2014; 43: 1096-1104.

51. Pillai O, Panchagnula R. Polymers in drug delivery. Curr Opin Chem Biol 2001; 5: 447-451.

52. Mangiapia G, Vitiello G, Irace C i wsp. Anticancer cationic ruthenium nanovectors: from rational molecular design to cellular uptake and bioactivity. Biomacromolecules 2013; 14: 2549-2560.

53. Santamaria R, Irace C, D'Errico G i wsp. Perspectives and potential applications of ruthenium-based nanocarriers for cancer therapy. J Pharm Drug Devel 2013; 1: e201.

54. Messori L, Camarri M, Ferraro T i wsp. Promising in vitro anti-Alzheimer properties for a ruthenium(III) complex. ACS Med Chem Lett 2013; 4: 329-332.

55. Michaelis ML, Ansar S, Chen Y i wsp. $\beta$-Amyloid-induced neurodegeneration and protection by structurally diverse microtubule-stabilizing agents. J Pharmacol Exp Ther 2005; 312: 659-668.

56. Carcelli $M$, Bacchi $A$, Pelagatti $P$ i wsp. Ruthenium arene complexes as HIV-1 integrase strand transfer inhibitors. J Inorg Biochem 2013; 118: $74-82 . x$ 